\title{
Electrical waves
}

\section{Ernst Lecher}

To cite this article: Ernst Lecher (1891) Electrical waves, Philosophical Magazine Series 5, 31:190, 290-291, DOI: 10.1080/14786449108620109

To link to this article: http://dx.doi.org/10.1080/14786449108620109

$$
\text { 曲 Published online: } 08 \text { May } 2009 .
$$

Submit your article to this journal

LII Article views: 2

Q View related articles ¿ 
the existence of simultaneous, but different wave-lengths proceeding from the same primary conductor may be established; only in air are the limits much closer than in wires. In order to obtain clear results the dimensions of the primary conductors must here bear a given ratio to that of the resonator, which does not differ greatly from unity.

For circles of the diameter $2 \mathrm{R}$, the distance of the node in air $\mathrm{L}$, and in the wires $\mathrm{D}$, there was obtained:-

$$
\begin{array}{ccccc}
2 \mathrm{R} & \ldots & 0 \cdot 26 \mathrm{~m} . & 0.36 & 0.75 \\
\mathrm{~L} & \ldots & 1 \cdot 12-1.25 \mathrm{~m} . & 1 \cdot 40-1.80 & 3 \cdot 00-3 \cdot 3 \\
\mathrm{D} & \ldots & 1.12 & 1.47 & 2 \cdot 96
\end{array}
$$

The waves in air are thus not at all, or but little, longer than in wires.-Archiv. de Genève, [3] xxii. p. 557 (1890); Beiblätter der Physik, vol. xiv. p. 1200 (1890).

\section{ON THE CONDUC'ION OF ELECTRICITY BY 'THE VAPOURS OF HEATED SALTS. BY SVANTE ARRHENIUS.}

The autbor gives a long and important paper on this subject; the method of experimenting was to produce the vapour in the flame of a Bunsen-burner, and to measure the conductivity between two platinum wires placed at a given distance from each other. The various experimental precautions are fully described and discussed; the experiments extended to various classes of salts, and the author sums up his conclusions as follows.

The extremely fruitful bypothesis of van't Hoff, that matter in the form of gas and in that of dilute solution has perfectly analogous properties, has so far been established in the most brilliant manner; and with the aid of the laws of gases a light has been thrown on the nature of solutions, hitherto undreamed of. In the present paper I have followed the reverse way, and with a knowledge of the electrolytic properties of dilute solutions the same properties which bave hitherto been unknown have been demonstrated in gases. Hence there is a complete analogy in this respect between the two conditions of matter.-Wiedemann's Annalen, vol. xlii. p. 18 (1891).

\section{ELECTRICAL WAVES. BY ERNST LECHER.}

The author descrites a new method of studying Hertz's phenomena. Instead of a resonator of the type employed by the latter. a Geissler tube is ustd. Two parallel wires of known self-juduction terminate at one end in condenser-plates, which are charged in an oscillatory manner by a large Rubmkorf coil excited by storage-cells. Upon the other ends of the parallel wires rests 
the Geissler tube. A short wire is then slid along the parallel wiras connecting them across like a bridge between two parallel wires on a sonometer. At certain definite points the Greissler tabe glows, and the wave-lengths of the electrical oscillations can thus be measured. Lecher finds that the velocity of electricity in metallic wires is the same as that of light. He points out a slight inaccuracy in Hertz's work.-American Journal of Science, Feb. 1891, p. 156; Ann. der Physik, Nov. 12, 1890, pp. 850-870.

\section{ON 'LHE HEAT OF EVAPORATION OH LIQUEFIED GASES. BY E. MATHIAS.}

The author uses a calorimetrical method of constant temperature; the heat withdrawn from the water-calorimeter by the evaporation of the gas is each moment restored by bringing strong sulphuric acid into the water of the calorimeter. It was therefore necessary to determine the heat of dilution of the sulpburic acid required for the measurements. With this view small glass flasks containing sulphuric acid were broken under water. A copper cylinder $3 \mathrm{~cm}$. in diameter and $9 \mathrm{~cm}$. in height was used as evaporator; this is connected at the top to a serpentine tube which was coiled several times round the cylinder, and on its emergence from the Berthelot's calorimeter it was insulated thermally from the rest of the tube by a connector of celluloid.

In the latter were two taps, a manometer, and finally a flask of special construction containing glycerine, in order accurately to control and regulate the rapidity of the ovaporation. The introduction of the sulphuric acid was effected by an apparatus of the nature of a wash-bottle. Those parts of the metal which came in contact with the acid were thickly gilded The author worked with sulphurous acid, nitrous oxide, and especially with carbonic acid with a range of temperature of $0^{\circ}$ to $31^{\circ}$. At the high temperatures the whole room was heated to the corresponding temperature.

In this way even the worst determinations did not differ by more than 2 per cent. from the mean. The results of experiments with $\mathrm{SO}_{2}$ and $\mathrm{CO}_{2}$ agree very well with those deduced from Clapeyron's equations. The differences with nitrous oxide arise from the gas being impure from the presence of nitrogen. With all three bodies the heat of evaporation decreases with increase of temperature within the interval in question. For sulphurous acid this is the linear equation,

$$
\lambda=91 \cdot 87-0 \cdot 384 t .
$$

For carbonic acid and nitrous oxide, whose critical temperatures are between $31^{\circ}$ and $36^{\circ} .4$, the decrease is very steep and can be well expressed by a function of the temperature of the second degree. For carbonic acid,

$$
\lambda^{2}=117 \cdot 303(31-t)-0 \cdot 466(31-t)^{2} .
$$

